\title{
Studi Sebaran Ukuran Butir Sedimen di Muara Sungai Jajar, Demak Jawa Tengah
}

\author{
Devi Yuni Sari Sihombing ${ }^{1 *}$, Muhammad Zainuri ${ }^{1}$, Lilik Maslukah ${ }^{1}$, Sugeng Widada $^{1}$ \\ dan Warsito Atmodjo ${ }^{1}$
}
${ }^{1}$ Departemen Oseanografi, Jurusan Ilmu Kelautan, Fakultas Perikanan dan Ilmu Kelautan, Universitas Diponegoro Jl. Prof. H. Soedarto, SH, Tembalang Semarang. 50275 Telp/Fax (024) 7474698
*Email: deviyunisarisihombin@student.undip.ac.id

\begin{abstract}
Abstrak
Demak adalah salah satu daerah di Jawa Tengah yang banyak memiliki permasalahan terkait erosi dan perubahan garis pantai. Perpindahan sedimen yang perlahan mengubah kondisi garis pantai merupakan mekanisme transpor sedimen yang dipengaruhi langsung oleh gelombang dan arus. Material sedimen yang terbawa menuju laut mengendap di dasar perairan. Proses pengendapan yang terjadi secara terus menerus menyebabkan penumpukan substrat sedimen. Wilayah Sungai Jajar merupakan daerah yang mengalami sedimentasi tinggi karena Sungai Jajar merupakan tempat pencampuran air dari persawahan, pertambakan, industri maupun kawasan penduduk. Sungai Jajar juga banyak dilintasi oleh nelayan - nelayan sekitar. Setiap tahun pengangkutan sedimen menuju laut dapat mencapai ribuan meter kubik. Tingkat sedimentasi yang tinggi ini berpotensi membawa pasokan sedimen masuk ke perairan Sungai Jajar sehingga dapat menyebabkan pendangkalan. Penelitian ini bertujuan untuk mengetahui persebaran ukuran butir sedimen di perairan Sungai Jajar Demak. Pengambilan data lapangan dilakukan pada tanggal 19 Agustus 2020 pada 9 titik stasiun dengan metode purposive sampling. Analisis sebaran ukuran butir sedimen di Demak pada bulan Agustus 2020 memiliki persebaran yang dominan silt dengan 79,99 \% silt ; 5,99 \% clay dan 16,05 $\%$ sand. Persebaran sedimen dasar menunjukan adanya hubungan faktor oseanografi yaitu arus dan pasang surut untuk menentukan pergerakan dan jenis sedimen yang ada di perairan.
\end{abstract}

Kata kunci : Persebaran, Sedimen, Muara sungai jajar, Demak.

\begin{abstract}
Demak is one of the areas in Central Java that has many problems related to erosion and shoreline changes. Sediment movement that slowly changes the conditions of the shoreline is a sediment transport mechanism that is directly affected by waves and currents. Sedimentary material carried to the sea settles on the bottom of the waters. The deposition process that occurs continuously causes the accumulation of sediment substrate. The Jajar River area is an area that experiences high sedimentation because the Jajar River is a place for mixing water from rice fields, aquaculture, industry and residential areas. The Jajar River is also widely traversed by local fishermen. Each year the transport of sediment to the sea can reach thousands of cubic meters. This high level of sedimentation has the potential to bring sediment supplies into the waters of the Jajar River, which can cause silting. This study aims to determine the distribution of sediment grain size in the waters of the Jajar Demak River. Field data collection was carried out on August 19, 2020 at 9 station points with a purposive sampling method. The analysis of the size distribution of the sediment grain in August 2020 has a dominant distribution of silt with 79,99\% silt; 5,99\% clay dan 16,05\% sand clay. The distribution of basic sediment shows that there is a relationship between oceanographic factors, namely currents and tides to determine the movement and type of sediment in the waters.
\end{abstract}

Keywords: $\quad$ Distibusion, Sediment, Estuary of Jajar, Demak. 


\section{PENDAHULUAN}

Pada Kabupaten Demak terdapat sungai yang melintasi beberapa wilayah kecamatan yaitu Sungai Jajar. Sungai Jajar merupakan salah satu sungai di Kabupaten Demak yang melintasi wilayah kecamatan Dempet, Kecamatan Bonagung, Kecamatan Wonosalam, Kecamatan Demak dan Kecamatan Bonang. Sungai tersebut berasal dari aliran sungai di Kecamatam Godong, Kabupaten Grobogan (Gulbuddin, 2014). Muara Sungai Jajar ini juga dimanfaatkan penduduk sekitar untuk jalur transportasi bagi nelayan. Tingkat sedimentasi di perairan akan sangat berkaitan dengan faktor-faktor oseanografi seperti arus dan pasang surut yang selanjutnya akan menentukan distribusi ukuran butir sedimen. Berdasarkan latar belakang diatas, penelitian bertujuan untuk mendapatkan sebaran ukuran butir sedimen dan mengkaitkannya dengan faktor oseanografi yang mempengaruhinya. Diharapkan melalui penelitian ini dapat membantu pencarian solusi terkait permasalahan mengenai proses sedimentasi di muara sungai Jajar. Ukuran butir sedimen dan kondisi perairan yang terjadi di perairan ini dapat memberikan gambaran mengenai distribusi tipe sedimen yang divisualisasikan dalam peta sebaran sedimen. Informasi yang telah diperoleh ini juga dapat menjadi input dan pertimbangan untuk pembangunan dinding pantai dalam menekan tingginya tingkat erosi di Sungai Jajar.

\section{MATERI DAN METODE PENELITIAN}

Materi yang digunakan pada penelitian ini sampel sedimen yang diambil dari-perairan muara sungai Jajar, Demak. Parameter oseanografi yang diukur meliputi arus, pasang surut, data angin.

Metode penentuan lokasi pengambilan sampel sedimen menggunakan metode purposive sampling yaitu berupa penentuan lokasi sampel dengan pertimbangan atau tujuan tertentu (Sugiyono, 2012). Penempatan 9 titik stasiun pada lokasi penelitian dapat dilihat pada Gambar 1. Penentuan jarak stasiun tersebut ditentukan mewakili muara sungai. Pengambilan sampel sedimen menggunakan sediment grab, dan selanjutnya dimasukkan ke plastik $( \pm 2 \mathrm{~kg})$.
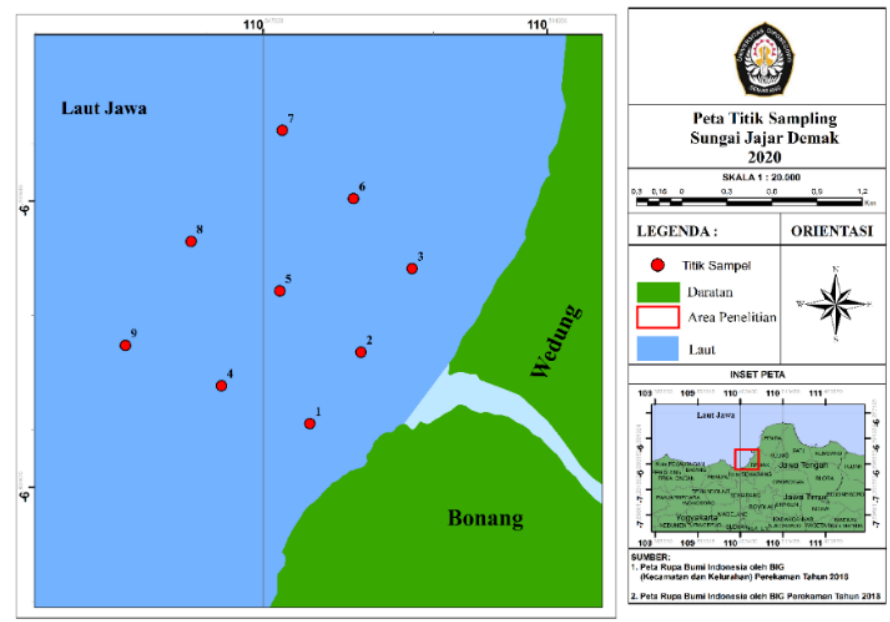

Gambar 1. Peta Lokasi Penelitian

\section{Metode Analisis Data \\ Metode Analisis Butir Sedimen}

Sampel sedimen diambil sebanyak 100 gram pada masing-masing stasiun untuk dilakukan proses sieving dan pemipetan. Proses pemisahan sedimen (sieving) sesuai ukuran butir menggunakan sieve shaker dengan amplitudo 60 dalam waktu 15 menit. Setelah proses pengayakan didapatkan nilai ukuran butir sedimen pada setiap lapisan mesh $(2 \mu \mathrm{m}, 0.5 \mu \mathrm{m}, 0.3 \mu \mathrm{m}, 0.150 \mu \mathrm{m}$ dan $0.063 \mu \mathrm{m},<0.063 \mu \mathrm{m})$. 
Sedimen yang berukuran sangat halus yaitu $<0,063$ tidak dapat diukur melalui sieve shaker sehingga harus dilakukan pemipetan. Pemipetan dilakukan dengan cara sedimen yang berada di mesh terdasar yaitu dengan ukuran butir 0,0625 dilarutkan dengan aquades sebanyak 1 Liter (Holme dan McIntyre, 1984).

\section{Metode Pengolahan Data Pasang Surut}

Data pasang surut diperoleh dari hasil pengolahan MIKE 21 dan dari Badan Informasi Geospasial, kemudian kedua datanya akan dibandingkan untuk proses verifikasi. Data pasang surut yang telah didapatkan kemudian diolah dengan menggunakan metode world tide untuk memperoleh nilai komponen pasang surut. (Ongkosongo,1989).

Kemudian, ditentukan pula tipe pasang surut pada lokasi penelitian tersebut:

$$
\mathrm{F}=\frac{K 1+O 1}{M 2+S 2}
$$

Keterangan:

F : bilangan formzahl

O1 : amplitudo komponen pasang surut tunggal utama yang disebabkan oleh gaya tarik bulan

K1 : amplitudo komponen pasang surut tunggal utama yang disebabkan oleh gaya tarik bulan dan matahari

M2 : amplitudo komponen pasang surut ganda utama yang disebabkan oleh gaya tarik bulan

S2 : amplitudo komponen pasang surut ganda utama yang disebabkan oleh gaya tarik bulan dan matahari

Untuk menentukan tipe pasang surut berdasarkan bil formzal $(\mathrm{F})$ menurut klasifikasi Ongkososno (19890) yang disajikan pada tabel 1.

Tabel 1. Klasifikasi Tipe Pasang Surut (Ongkosongo, 1989)

\begin{tabular}{ll}
\hline Nilai $\mathrm{F}$ & Tipe pasang Surut \\
\hline $0,00<\mathrm{F}<0,25$ & Pasang harian ganda beraturan \\
$0,25<\mathrm{F}<1,50$ & Pasang campuran condong ke harian ganda \\
$1,50<\mathrm{F}<3,00$ & Pasang campuran condong ke harian tungggal \\
$\mathrm{F}>3,00$ & Pasang harian tunggal beraturan \\
\hline
\end{tabular}

\section{Metode Pengolahan Data Arus Laut}

Data arus yang diperoleh dari Pemodelan Hidrodinamika kemudian diolah dalam MIKE 21. Kemudian data tersebut dikelolah di ArcGIS 10.4 untuk memperoleh persebaran Arus di sungai Jajar Demak. Data arus ini digunakan untuk mengetahui kecepatan dan arah arus pada daerah penelitian yaitu sungai Jajar demak.

\section{HASIL DAN PEMBAHASAN}

Menurut Triatmodjo (1999), Sedimen yang sudah melalui tahap pengayakan dan pipetting tersebut dihitung persentase kumulatifnya untuk mencari nilai D50, untuk memperoleh nilai parameter statistik. Klasifikasi butiran dilakukan berdasarkan nilai diameter referensi (D50) dari material dasar.

Hasil analisis laboratorium yang didapatkan untuk ukuran butir sedimen menunjukkan bahwa pada stasiun 1,2,3,4,5,6,7,8,9, memiliki kandungan sedimen yang tersusun dari silt dan clay, dengan kisaran ukuran butir sedimen diantara $0.044-0.062$. Hasil selengkapnya disajikan pada Tabel 2 dan pola distribusinya disajikan pada Gambar 2. 
Tabel 2. Tabel Penamaan dan Ukuran Butir Sedimen Dasar Tiap Stasiun (Pengolahan Data, 2020)

\begin{tabular}{cccccc}
\hline Titik & \multicolumn{3}{c}{ Kandungan (\%) } & Nama sedimen & $\begin{array}{c}\text { Ukuran Butir } \\
\text { Stasiun }\end{array}$ \\
\cline { 2 - 4 } & Sand & Silt & Clay & & 0,044 \\
\hline 1 & $30.02 \%$ & $61.70 \%$ & $8.28 \%$ & Lanau Pasiran & 0,059 \\
2 & $26.48 \%$ & $65.99 \%$ & $7.54 \%$ & Lanau Pasiran & 0,047 \\
3 & $51.36 \%$ & $43.71 \%$ & $4.93 \%$ & Pasir Lanauan & 0,052 \\
4 & $15.05 \%$ & $78.19 \%$ & $6.76 \%$ & Lanau & 0,051 \\
5 & $7.97 \%$ & $89.29 \%$ & $2.73 \%$ & Lanau & 0,05 \\
6 & $5.00 \%$ & $83.82 \%$ & $11.18 \%$ & Lanau & 0,049 \\
7 & $3.42 \%$ & $93.17 \%$ & $3.41 \%$ & Lanau & 0,062 \\
8 & $4.26 \%$ & $89.99 \%$ & $5.75 \%$ & Lanau & 0,044 \\
9 & $0.93 \%$ & $95.80 \%$ & $3.27 \%$ & Lanau & \\
\hline
\end{tabular}
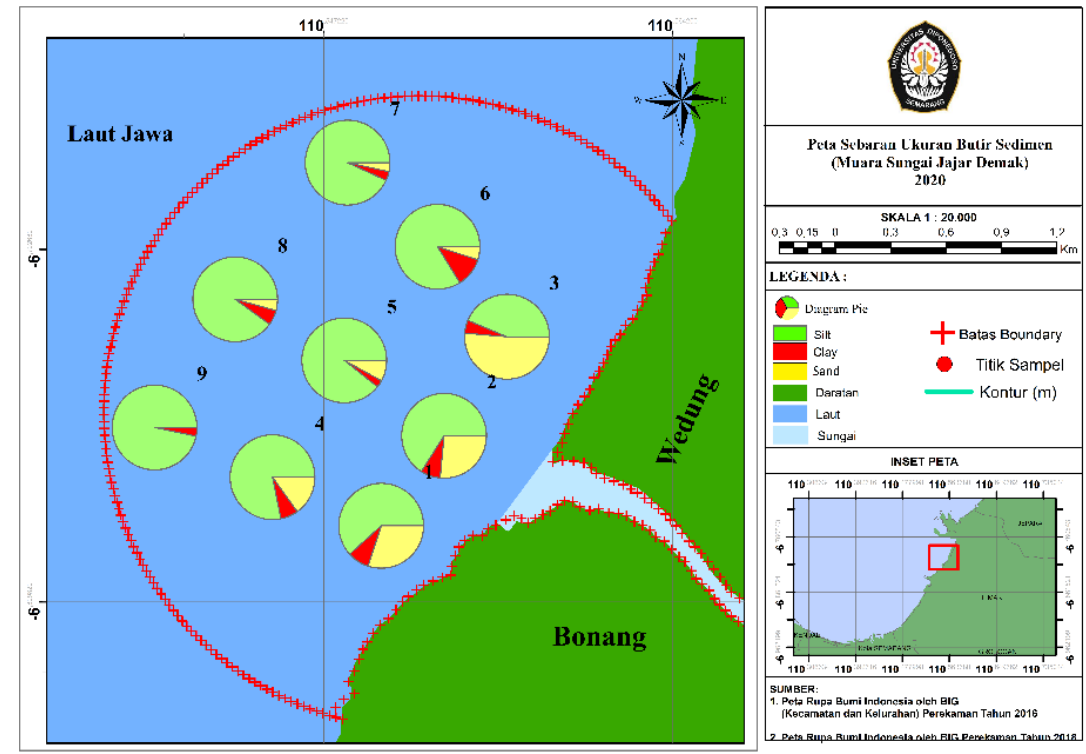

Gambar 2. Peta Sebaran Sedimen Permukaan Dasar Laut Tiap Stasiun (Pengolahan Data, 2020)

Berdaarkan peta sebaran sedimen dasar pada Gambar 2, sebaran ukuran butir sedimen di bagi menjadi 3 warna pengelompokkan ukuran butir sedimen dan disajikan dalam bentuk diagram pie pada setiap stasiun. Warna hijau muda menggolongkan ukuran butir sedimen silt, warna kuning menggolongkan ukuran butir sedimen sand dan warna merah menggolongkan ukuran butir sedimen clay. Pada semua titik di stasiun, warna yang dominan adalah warna hijau yaitu dominan ke ukuran butir silt. Ukuran butir sedimen yang mendominasi pada stasiun tersebut adalah ukuran butir sedimen silt.

Hasil analisis pasang surut dengan software World Tide pada perairan Sungai Jajar Demak, menghasilkan komponen-komponen pasang surut yang digunakan untuk menentukan nilai HHWL, LLWL, MSL dan nilai Formzahl (F) seperti pada Tabel 3. Nilai yang dihasilakan yaitu HHWL sebesar 0,519 m, nilai LLWL sebesar - 0,52 dan nilai MSL sebesar $0 \mathrm{~cm}$. Untuk menuntukan tipe pasang surut pada perairan Sungai Jajar Demak dapat di tentukan dengan nlai Formzahl (F) yang telah didapatkan. Nilai Formzahl (F) 
yang didapatkan yaitu 1,932 dengan demikian tipe pasang surut di perairan Sungai Jajar Demak tergolong tipe campuran condong ke harian tunggal dengan fenomena satu hari terjadi satu kali air pasang dan satu kali air surut. Hasil ini juga diperkuat oleh peneliti Manurung (2017), tipe pasang surut perairan Demak tergolong ke tipe pasang surut campuran condong harian tunggal.

Tabel 3. Hasil Akhir Pengolahan Data Pasang Surut (Pengolahan Data, 2020 )

\begin{tabular}{ccc}
\hline Komponen & Amplitudo $(\mathbf{c m})$ & Beda Fase $\left(^{\circ}\right)$ \\
\hline $\mathrm{S}_{0}$ & 189.88 & 0 \\
$\mathrm{M}_{2}$ & 7.47 & 357.63 \\
$\mathrm{~S}_{2}$ & 7.13 & 305.07 \\
$\mathrm{~N}_{2}$ & 2.87 & 292.36 \\
$\mathrm{~K}_{1}$ & 23.35 & 247.94 \\
$\mathrm{O}_{1}$ & 7.80 & 95.24 \\
$\mathrm{M}_{4}$ & 0.66 & 18.15 \\
$\mathrm{MS}_{4}$ & 0.43 & 272.08 \\
$\mathrm{~K}_{2}$ & 1.93 & 305.07 \\
$\mathrm{P}_{1}$ & 7.70 & 247.94 \\
\hline
\end{tabular}

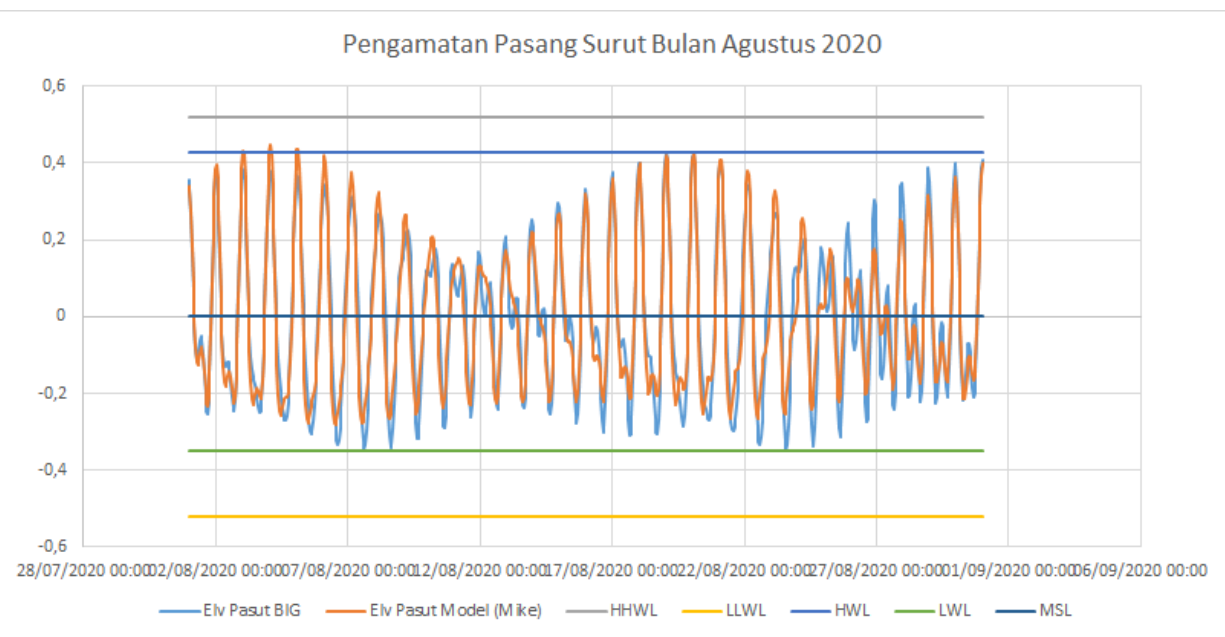

Gambar 4. Grafik Pengamatan Pasang Surut (Pengolahan Data, 2020)

Pada rafik pengamatan pasang surut yang terjadi pada bulan Agustus 2020 (Gambar 4) menunjukkan bahwa tipe pasang surut yang terjadi adalah campuran condong ke harian tunggal. Pada tanggal 01 hingga 31 Agustus 2020 terjadi pasang surut campuran condong ke harian ganda dengan periode dan tinggi yang berbeda yang dapat dilihat pada Gambar 4. Pada tanggl 19 agustus 2020 tipe pasang surut yang terjadi adalah pasang surut tipe campurang condong ke harian tunggal. Kawasan pantai yang mengalami proses pasang lebih lama daripada surut akan memberikan kesempatan yang lebih banyak bagi gelombang untuk mengerosi pantai suatu daratan (Triatmodjo, 1999). 
Hasil perhitungan arah dan kecepatan arus pada saat pasang tertinggi di tanggal 19 agustus 2020 menggunakan pemodelan MIKE 21 menunjukkan nilai kecepatan maksimum sebesar 0,197 m/det dan kecepatan arus minimum sebesar $0,000210 \mathrm{~m} /$ det yang ditunjukkan pada Gambar 5. Arus pada saat pasang tertinggi dan surut terendah ditandai dengan gerak bolak balik yaitu apabila pada saat surut. Sedangkan hasil perhitungan arah dan kecepatan arus pada saat surut di tanggal 19 Agustus 2020 menggunakan pemodelan MIKE 21 menunjukkan nilai kecepatan maksimum sebesar 0,085 m/det dan kecepatan arus minimum sebesar 0,000915 m/det yang ditunjukkan pada Gambar 6.
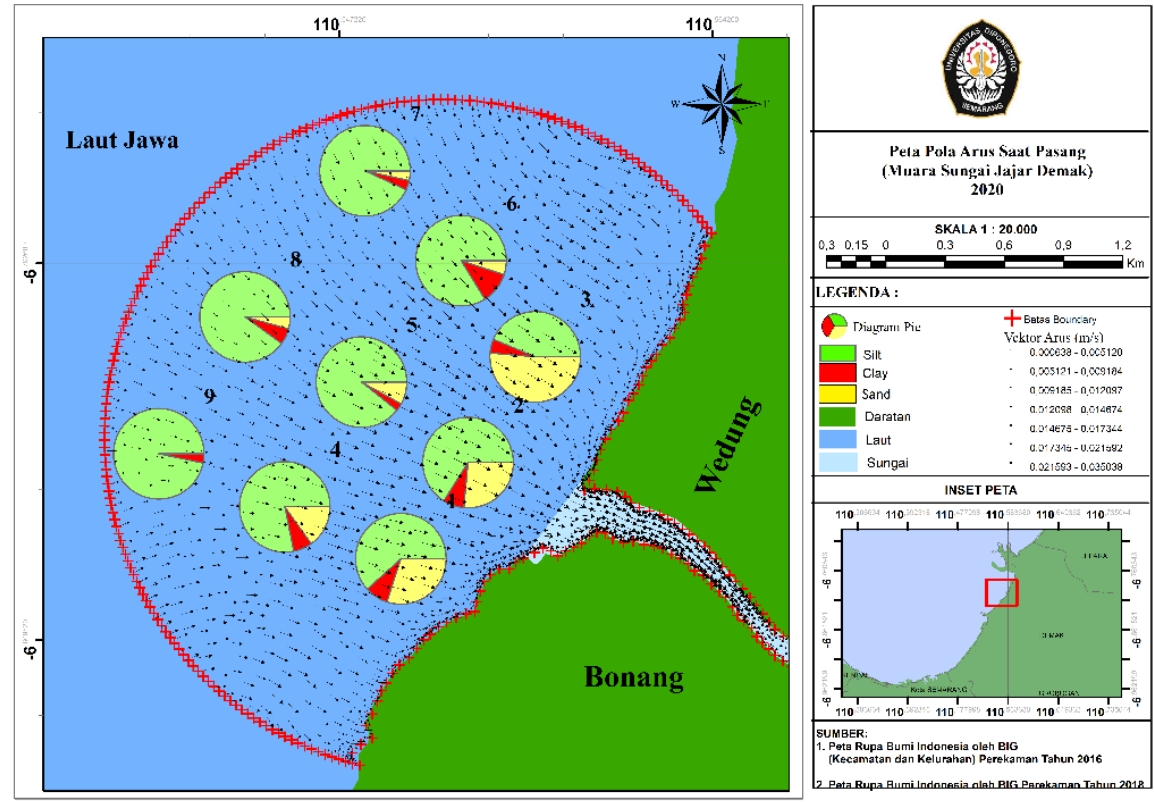

Gambar 1. Pola Arus Saat Pasang (Pengolahan Data, 2020)
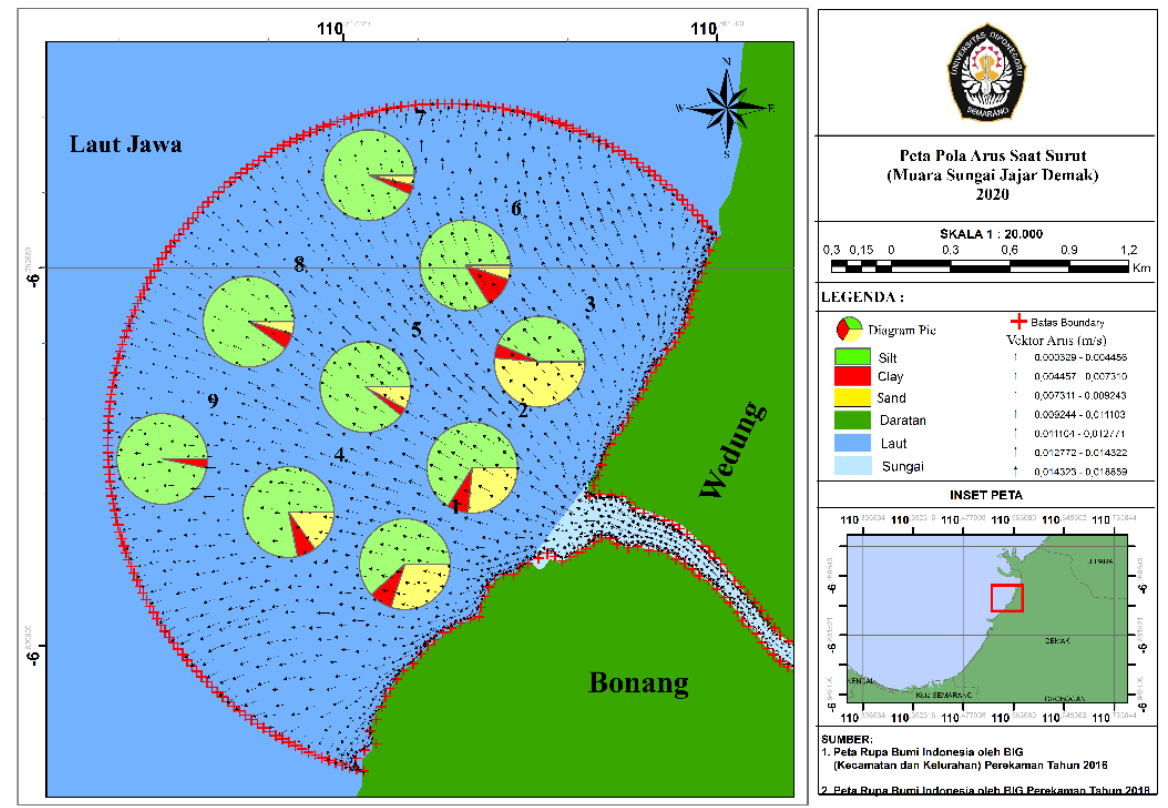

Gambar 2. Pola Arus Saat Surut 


\section{Pembahasan}

Hasil pengamatan terhadap kandungan dan sebaran sedimen menunjukan bahwa pada beberapa stasiun mempunyai kandungan dominan yaitu silt, dengan nilai berkisar $61,70 \%-95,80 \%$ yang terdapat pada stasiun 1, 2, 4, 5, 6, 7, 8,9, dan 10. Selanjutnya untuk kandungan sand pada beberapa stasiun dominan ke stasiun 3 dengan nilai 51,36\%.dan untuk kandungan clay pada setiap stasiun adalah 2,27\% - 11,18\%. Namun demikian berdasarkan nilai dari stasiun, maka diperoleh stasiun 1, 3, menuju stasiun 4 hingga stasiun 7 (dari garis pantai menuju laut), menunjukkan nilai silt lebih tinggi dari stasiun lainya. Sedangkan stasiun 2, 5, 6, 7, 8 dan 9 mempunyai pola kuadratik, dimana nilai tertinggi ada pada stasiun 9 sebesar 95,80\% dan stasiun 7 sebesar 93,17\%. Hal ini menunjukkan bahwa sebaran silt bertumpu atau berpusat dari stasiun 5, 7 dan 9 atau berdasarkan arah dari Selatan menuju Utara. Hal ini menunjukkan bahwa sebaran bertumpu atau berpusat dari stasiun 1, 5 dan 6 atau berdasarkan arah dari selatan menuju utara. Selanjutnya Juni (2015), menyatakan bahwa sedimen di perairan Sayung Demak tersusun atas kandungan sand, silt dan clay. Sedimen dasar di Sungai Jajar Demak secara umum bergerak mengikuti pola kontur arus, di mana pola kontur arus Perairan Sungai Jajar Demak secara umum teratur dan landai. Sedimen pada muara Sungai Jajar didominasi oleh jenis ukuran butir berbentuk silt, dikarenakan adanya pergerakan arus laut yang memiliki kecepatan relatif kecil yaitu $0,000210 \mathrm{~m} / \mathrm{s}$ sehingga tidak mampu mengangkut butiran sedimen yang mengakibatkan sedimen mengendap pada daerah tersebut dan juga sebagian besar inputan sedimen dari DAS adalah berupa sedimen berukuran silt.

Sedimen pada perairaan Muara Sungai Jajar Demak memiliki nilai diameter ukuran butir sedimen $\left(\mathrm{D}_{50}\right)$ hampir merata disetiap titik lokasi dengan kisaran antara 0,044-0,062 mm. Kecepatan endap partikel sedimen menunjukkan besaran dengan pola yang sama terhadap ukuran rerata sedimen. Hal ini menunjukkan bahwa daerah tersebut memiliki tingkat kecepatan pengendapan sedimen yang bervariasi bisa cepat bisa lambat. Sedimen silt berada pada perairan yang lebih dalam. Perbedaan ukuran butir juga berhubungan dengan sumber sedimen. Semakin menjauhi arah pantai ataupun teluk maka ukuran butir yang diperoleh akan semakin halus (Nugroho dan Basit, 2014). Hal ini dikarenakan sedimen silt mengalami proses sedimentasi di Muara Sungai Jajar Demak karena ukuran butir yang lebih besar daripada clay. Sedangkan clay tidak sempat mengalami pengendapan sehingga tidak terendapkan di daerah muara sungai jajar demak dan menyebabkan presentasi yang jauh lebih kecil sehingga mudah terbawa arus menuju laut lepas. Keadaan ini menunjukkan bahwa sumber sedimen telah mengalami proses transportasi sampai akhirnya mengalami pengendapan pada masing-masing lokasi penelitian. Hal ini didukung oleh pernyataan Dyer (1986) yang menyebutkan bahwa sedimen dengan ukuran yang lebih halus lebih mudah berpindah dan cenderung lebih cepat bergerak daripada ukuran kasar..

Hasil pengamatan untuk kecepatan arus dan arah arus pada daerah pantai menunjukan bahwa pergerakan arus pada saat pasang lebih dominan memasukin muara sungai dengan arah arus tenggara dan pada daerah laut lebih dominan kearah timur laut. Pada stasiun 1 hingga stasiun 9 pergerakan arus lebih dominan bergerakan kearah timur laut. Kecepatan arus yang terjadi pada saat pasang yaitu 0,000210 m/s $0,120 \mathrm{~m} / \mathrm{s}$. Pada pola arus saat surut memiliki arah arus dominan menuju barat daya dengan kecepatan arus dari $0,00030 \mathrm{~m} / \mathrm{s}-0,0712 \mathrm{~m} / \mathrm{s}$. Kecepatan arus yang lemah menyebabkan hanya butiran sedimen yang kecil yang dapat terangkut, sehingga sedimen yang halus seperti lanau sangat mendominasi sebaran sedimen dasar di perairan sungai jajar demak. Arus yang mempengaruhi sebaran sedimen dasar adalah arus pada kolom dasar perairan. Kecepatan arus yang kecil pada dasar perairan menyebabkan arus hanya mampu mengangkut sedimen yang halus sesuai dengan besarnya energi dari arus tersebut. Arus juga akan mengangkut sedimen searah dengan arah pergerakan arusnya. Pengendapan sedimen pasir terjadi pada saat arus yang menguat, sedangkan pengendapan sedimen lanau dan lempung terjadi karena melemahnya arus. Hubungan antara kecepatan arus dengan diameter sedimen dan pengaruhnya terhadap pergerakan sedimen adalah semakin menguatnya arus akan mengendapkan sedimen kasar, dan dengan melemahnya arus akan mengendapkan sedimen halus di suatu perairan. 


\section{KESIMPULAN}

Secara umum persebaran ukuran butir sedimen di perairan Muara Sungai Jajar Demak terdiri dari fraksi silt dan clay. Persebarannya sedimen dengan ukuran yang lebih halus lebih mudah berpindah dari permukaan pantai menuju laut dan cenderung lebih cepat bergerak daripada ukuran kasar dikarenakan adanya pergerakan arus pasang surut yang membawa sedimen halus lebih dominan kearah laut. Persebaran sedimen pada Muara Sungai Jajar dapat disebabkan oleh suplai sedimen dari DAS Sungai Jajar yang merupakan hilir dari Sungai Jajar Demak, yang membantu membawa sedimen dari hilir suangi menuju laut. Ukuran butir sedimen yang mendominasi di perairan Sungai Jajar Demak adalah sedimen dengan ukuran butir silt. Sedangkan ukuran butir sedimen lainnya yang tidak mendominasi yaitu sedimen dengan ukuran butir clay dan sedimen dengan ukuran butir sand. Butiran sedimen disungai Jajar, Demak tersusun oleh yaitu sand, clay, silt. Sedimen tersusun atas 79,99\% silt ; 5,99\% clay dan 16,05\% sand.

Faktor oseanografi yang dominan mempengaruhi sebaran ukuran butir sedimen adalah Arus pasang surut. Hal ini dibuktikan dengan persebaran ukuran butir yang lebih dominan ke silt dan clay pada Muara Sungai Jajar Demak.

\section{DAFTAR PUSTAKA}

Denestiyanto, R., \& H. Setiyono. 2015. Analisis Karakteristik Gelombang Di Perairan Kabupaten Batu Bara, Sumatera Utara. Journal of Oceanography, 4(2), 400-407 Hlm.

Duxbury, A.B., A.C. Duxbury, \& K.A. Sverdrup. 2002. Fundamentals Of Oceanography. Mcgraw Hill Companies, New York, 111-117 Hlm.

Dyer, K.R.,1986. Coastal and Estuary Sediment Dynamic. John Willey \& Sons.Chichester.

Febriyanti, L., P. W. Purnomo., \& Churun A'in. 2017. Karakteristik Oseanografi Dan Sedimentasi Di Perairan Tererosi Desa Bedono, Demak Pada Musim Barat. Journal Of Maquares , 6(4) : 367-375 Hlm.

Gulbuddin, A. D. Q., A Satriadi., \& H Setiyono. 2014. Analisa Pengaruh Pasang Purnama (Spring) Dan Perbani (Neap) Terhadap Laju Sedimentasi Di Perairan Timbulsloko, Demak. Jurnal Oseanografi, 3(4) : 540 - $548 \mathrm{Hlm}$.

Hambali, R.2016. Studi Karakteristik Sedimen Dan Laju Sedimentasi Sungai Daeng - Kabupaten Bangka Barat. Jurnal Fropil, Jurnal Teknik Sipil Fakultas Teknik Universitas Bangka Belitung Vol 4 (2) ; $165 \mathrm{Hlm}$.

Hawati, P., D. N. Sugianto., S. Anggoro., A. Wirasatriya., \& S. Widada. 2017. Waveinclude Sediment Transport At Coastal Region Of Timbulsloko Demak. In IOP Conference Series: Earth and Environmental Science, 55(1) : 1 - $8 \mathrm{Hlm}$.

Holme, \& McIntyre. 1984. An Introduction to Coastal. New York: Harper and Row Publisher.

Hutabarat, S., \& Evans . 1985. Pengantar Oseanografi. Ui-Press, Jakarta, $159 \mathrm{Hlm}$

Ismanto, A., Zainuri, M., Hutabarat, S., Sugianto, D. N., Widada, S., \& Wirasatriya, A. 2017. Sediment Transport Model In Sayung District, Demak. In IOP Conference Series: Earth and Environmental Science Vol 55 (1). IOP Publishing.

Jenhar J. H., M. Yusuf., \& E. Indrayanti. 2013. Dinamika Penjalaran Gelombang Menggunakan Model Cms-Wave Di Pulau Parang Kepulauan Karimunjawa. Jurnal Oseanografi, 2(3) : 255-264

Juni , M. P., Muslim \& H. Suseno. 2015. Studi Sebaran Sedimen Berdasarkan Tekstur Sedimen Di Perairan Sayung, Demak. Jurnal Oseanografi. Vol 4(3); 608 - 613 Hal.

Lestari, S. S., M. R. Muskananfola., \& W. T. Taufani. 2018. Analisis Tekstur Sedimen Dan Bahan Organik Terhadap Kelimpahan Makrozoobenthos Di Muara Sungai Jajar, Demak. Journal Of Maquares, 7 (4) : 423-430.

Nugroho, D. S ., S. Widada ., A. Wirasatriya ., A Ismanto ., A. Darari., \& Suripin. 2017. Modelling Of Suspended Sediment Transport In Coastal Demak Indonesia By Using Currents Analyzing. Arpn Journal Of Engineering And Applied Sciences, 12 (16) : 4666- 4667 Hlm

Nugroho, S. H., \& Basit, A. (2014). Sediment distribution based on grain size analyses in Weda Bay, 
Northern Maluku. Jurnal Ilmu dan Teknologi Kelautan Tropis, 6(1) ; 229-240 Hlm.

Ongkosongo, O. S. R. 1989. Penerapan Pengetahuan Dan Data Pasang-Surut Dalam Pasang-Surut, Pusat Penelitian Dan Pengembangan Oseanologi-Lipi. Jakarta : 241-254 Hlm.

Qhomariyah, L. \& Yuwono. 2016. Analisa Hubungan Antara Pasang Surut Air Laut Dengan Sedimentasi Yang Terbentuk (Studi Kasus : Dermaga Pelabuhan Petike Mas Surabaya). Jurnal Teknik Its, 5(1) : F1-F3. Issn: 2337-3539.

Safwan, M. A., S. Widada., \& P. Subardjo. 2016. Pengaruh Arus Sepanjang Pantai (Longshore Current) Terhadap Sebaran Sedimen Dasar Di Perairan Teluk Awur, Jepara. Jurnal Oseanografi. 5 (4) : 415 - $424 \mathrm{Hlm}$.

Sugiyono. 2012. Metode Penelitian Kuantitatif, Kualitatif , Dan R\&D. Alfabeta, Bandung, 330 Hlm. Triatmodjo, B. 1999. Teknik Pantai. Beta Offset, Yogyakarta, 397 Hlm

Widada, S. 2015. Geologi Wilayah Pesisir. Modul Pelatihan Perencanaan Tata Ruang Di Wilayah Pesisir. Hal : 29-61 